\title{
Pengembangan Media Animasi untuk Pembelajaran Matematika Materi Bangun Datar
}

\author{
Windu Antaka Adi ${ }^{*}$, Stefanus C. Relmasita², Agustina Triyas Hardini ${ }^{3}$ \\ 123 Pendidikan Guru Sekolah Dasar, FKIP - Universitas Kristen Satya Wacana
}

\begin{abstract}
Abstrak
Keywords:

Penelitian ini merupakan penelitian pengembangan, yaitu pengembangan multimedia interaktif dengan Adobe Flash Player CC, pada mata pelajaran Matematika kompetensi dasar Memahami sifat-sifat Bangun Datar, hubungan antar Multimedia Interaktif, Adobe Flash Player $C C$ Bangun Datar, dan rumus Bangun Datar dengan memanfaatkan perkembangan teknologi. Penelitian ini dilakukan untuk mengetahui peningkatan hasil belajar pada pembelajaran Matematika dengan menggunakan multimedia interaktif. Serta untuk menciptakan suatu media yang dapat digunakan siswa untuk belajar secara mandiri dirumah. Tahap pengembangan dilakukan dengan metode pengembangan 4D meliputi Pendefinisian (define), Perencanaan (design), Pengembagan (develop), dan Penyebaran (Disseminate) melalui ujicoba terbatas pada 10 siswa dan ujicoba lebih luas seluruh siswa kelas IV SD Negeri Sampetan. Berdasarkan hasil analisis data penelitian menunjukkan bahwa multimedia interaktif dikembangkan layak digunakan, dinilai dari segi pakar media, matei dan pembelajaran mendapat rata-rata hasil baik dan cukup, secara hasil diperoleh peningkatan nilai rata-rata dari 60 menjadi 85, efisien dalam mencapai tujuan pembelajaran dengan waktu yang dibutuhkan hanya 1 kali pertemuan untuk menyampaikan materi, dan selebihnya digunakan untuk latihan soal dan penugasan, serta memiliki daya tarik bagi siswa dengan kemenarikan 85\%. dapat disimpulkan bahwa multimedia interaktif yang dibuat dapat meningkatkan hasil belajar siswa dalam pembelajaran Matematika materi Bangun Datar.
\end{abstract}

\section{PENDAHULUAN}

Pendidikan saat ini telah mengalami kemajuan yang begitu pesat dapat kita lihat dari penggunaan media untuk pendukung pembelajaran yang mulai dikembangkan oleh pengembang ataupun guru dan sekolah. Selain itu, pembelajaran yang kontekstual dapat menstimulus otak anak untuk memahami materi pelajaran. Konsep pembelajaran ini juga identik dengan pembelajaran realistis, yaitu pembelajaran yang menggunakan resources atau media yang dekat dengan kehidupan anak didik (Musfiqon, 2012: 187). Multimedia interaktif merupakan suatu bentuk teknologi informasi yang digunakan dalam optimasi kegiatan belajar mangajar (Sanjaya, 2016:100). Hal ini ditunjukkan dengan adanya berbagai teknologi seperti media audio visual, internet, multimedia interaktif, LCD, komputerisasi dan lain sebagainya yang dapat digunakan dalam proses pembelajaran. Pemanfaatan teknologi merupakan kebutuhan mutlak dalam dunia pendidikan saat ini sehingga lembaga pendidikan (sekolah) benar-benar menjadi ruang belajar dan tempat siswa mengembangkan kemampuannya secara optimal. Media berbasis teknologi pada saat ini sangat dibutuhkan dalam proses pembelajaran. Hal ini dilakukan untuk menciptakan kualitas siswa yang tidak hanya bergantung melalui transfer ilmu secara verbal, tetapi lebih dari itu bisa didapat melalui berbagai sumber termasuk media berbasis teknologi. Tidak hanya sekolah yang dapat menjadi tempat untuk belajar siswa tetapi (rumah) merupakan tempat yang baik untuk belajar siswa dengan pengawasan dari orang tua. Menurut Sukiyasa (2013) Ditinjau dari sudut pandang pendidik, guru harus

* Corresponding author. 
dapat mengintegrasikan kemampuannya dalam mengelola pembelajaran di kelas, salah satunya bagaimana penggunaan media untuk mempermudah penyampaian materi, serta mempermudah penerimaan materi pelajaran oleh siswa. Dengan demikian, perlu upaya untuk menjembatani permasalahan tersebut demi tercapainya keberhasilan pengajaran. Dalam hal ini penggunaan media berupa animasi yang dapat memvisualisasikan sesuatu yang abstrak.

Media memiliki peranan penting dalam pembelajaran, yaitu dapat meningkatkan antusias siswa, sehingga siswa tertarik dan memberikan perhatiannya pada pelajaran tersebut. Media pembelajaran adalah media yang membawa pesan-pesan atau informasi yang bertujuan intruksional atau mengandung maksud-maksud pengajaran (Hamdani, 2010:243). Seperti halnya yang dikemukakan oleh Hamalik (dalam Arsyad, 2007:15) bahwa pemakaian media pembelajaran dalam proses belajar mengajar dapat membangkitkan keinginan dan minat yang baru, membangkitkan motivasi dan rangsangan kegiatan pembelajaran dan bahkan membawa pengaruh-pengaruh psikologis terhadap siswa. Multimedia berfungsi menjadikan visualisasi pembelajaran lebih nyata dan lebih interaktif. Penggunaan multimedia interaktif ini diharapkan dari segi waktu dan kejelasan materi pembelajaran dapat tersampaikan dengan baik, sehingga tujuan pembelajaran bisa tercapai. Menurut Agustien (2018) Media pembelajaran selain dapat menggantikan sebagian tugas pendidik sebagai penyaji materi, media juga memiliki potensi-potensi yang unik yang dapat membantu peserta didik dalam belajar. Oleh sebab itu, perlu dikembangkan media pembelajaran yang kreatif yang dapat meningkatkan daya tarik peserta didik untuk belajar sejarah. Beberapa alternatif media pembelajaran yang dapat dimanfaatkan dalam pembelajaran sejarah salah satunya adalah media video. Menurut Johari (2014) Media animasi merupakan pergerakan sebuah objek atau gambar sehingga dapat berubah posisi. Selain pergerakan, objek dapat mengalami perubahan bentuk dan warna. Media animasi dalam pembelajaran berfungsi menarik perhatian siswa untuk belajar sehingga dapat memberi pemahaman yang lebih cepat.

Pada saat ini, penggunaan media dalam pembelajaran sudah banyak diterapkan dibeberapa sekolah, termasuk di SD Negeri Sampetan. Media pembelajaran di sekolah tempat penelitian ini dilakukan sering digunakan, salah satunya media LCD, dan alat peraga Matematika. Media tersebut memiliki kelebihan dapat mempermudah siswa dalam mengingat pelajaran yang disampaikan karena penyampaiannya dapat dilakukan secara nyata. Namun juga memiliki kekurangan yaitu media tersebut kurang animatif karena hanya menampilkan tulisan dan gambar diam, juga kurang interaktif karena media tersebut sifatnya satu arah, serta kurang efektif karena beberapa media tidak dapat digunakan untuk seluruh siswa dalam satu kelas dikarenakan jumlah media yang terbatasi. Penggunaan media tersebut dirasa masih kurang membantu guru dalam menyampaikan materi, terutama kompetensi dasar memahami sifat-sifat bangun datar, hubungan antar bangun datar, dan mengidentifikasi sifat-sifat bangun datar, karena materi itu butuh banyak contoh agar mudah dipahami.

Proses pembelajaran terkadang juga mengalami hambatan bisa dari guru atau media yang digunakan dalam pembelajaran, Jika dalam pembelajaran masih mengalami hambatan maka tujuan dari pembelajaran tersebut tidak akan tercapai secara maksimal. Dalam pembelajaran Matematika media haruslah dapat membuat siswa menjadi paham dan mengerti terhadap suatu konsep sehingga pembelajaran dapat dikatakan tercapai, pembelajaran Matematika tidak hanya mengajarkan suatu bentuk pemahaman yang dipelajari secara membaca atau menyimak tetapi pembelajaran lebih kepada bagaimana siswa menyelesaikan suatu masalah yang ada. Tujuan penelitian ini adalah untuk membuat media animasi sebagai alat peraga yang baru, sebagai perbaikan atau pengganti media dan alat peraga yang terdahulu serta melihat efektifitasnya yang ditujukan pada keterampilan hipotesis siswa dan hasil belajar. Menurut Asmara (2015) Media pembelajaran adalah salah satu contoh faktor eksternal yang dapat dimanfaatkan untuk meningkatkan efisiensi belajar. Hal itu dapat tercapai karena media pembelajaran dapat mengatasi berbagai hambatan, antara lain: hambatan komunikasi, keterbatasan ruang kelas, sikap siswa yang pasif, pengamatan siswa yang kurang seragam, sifat objek belajar yang kurang khusus sehingga tidak memungkinkan dipelajari tanpa media, tempat belajar yang terpencil dan sebagainya. Media pembelajaran menempati posisi yang strategis dalam proses pembelajaran karena menjadi perantara informasi pengetahuan dari guru kepada siswanya. Banyak manfaat yang diberikan media pembelajaran kepada siswa.

Pembelajaran dengan menggunakan multimedia interaktif, mampu mengaktifkan siswa untuk belajar dengan motivasi tinggi karena ketertarikannya pada sistem multimedia yang mampu menyuguhkan tampilan teks, gambar, video, suara dan animasi (Deni Darmawan, 2012:55-56). Hakekat matematika menurut Huri Suhendri (2011) yaitu kebenarannya berdasarkan logika atau pemikiran, objeknya abstrak, melatih kemampuan berhitung dan berpikir secara logis serta aplikatif. Dengan multimedia interaktif suatu pembelajaran dengan bentuk penyelesaian masalah dapat diciptakan, dengan beberapa keunggulan yang dimiliki oleh multimedia interaktif. Diantaranya pembelajaran lebih interaktif karena media dapat digunakan oleh siswa secara mandiri dengan memanfaatkan media lain, sehingga 
siswa tidak terpaku dengan proses penyampaian materi yang diberikanoleh guru. Kedua pembelajran akan lebih inovatif dengan adanya berbagai materi yang ada dalam media, seperti teori dan konsep matematika, gambar mengenai bagaimana bangun datar terbentuk, video animatif, dan animasi sederhana yang mampu membuat siswa lebih paham mengenai konsep Matematika. Ketiga pembelajaran lebih atraktif karena didalam media tersebut terdapat berbagai soal dan quis yang dapat digunakan siswa untuk memperdalam wawasan mengenai materi yang sedang dipelajari, dan guru dapat secara langsung menilai hasil belajar siswa melalui nilai quis dan tes yang ada didalam media.

Berdasarkan pengamatan yang dilakukan dalam pembelajaran yang terjadi sebelumnya dan wawancara terhadap Kepala Sekolah ataupun dengan guru kelas IV, menghendaki adanya perubahan dalam pemanfaatan media yang ada di sekolah sehingga pembelajaran lebih inovatif dan bervariatif mengingat karekteristik pembelajaran Matematika mempelajari mengenai konsep yang kompleks. Dengan adanya multimedia interaktif diharapkan dapat mempermudah siswa dalam menerima materi pelajaran, meningkatkan antusias siswa untuk belajar mandiri, serta meningkatkan pemahaman siswa mengenai konsep Matematika sehingga siswa tidak terpaku pada konsep memgingat suatu materi tetapi memahami materi tersebut.

Berdasarkan analisis kebutuhan diatas yang ada perlu dilakukan pengembangan mulirmedia interaktif dengan Adobe Flash Player CC pada mata pembelajaran Matematika kompetensi dasar Memahami sifat-sifat Bangun Datar, hubungan antar Bangun Datar, dan rumus Bangun Datar di SD Negeri Sampetan. Produk yang dihasilkan dari pengembangan ini berupa CD interaktif, tujuan dari pengembangan multimedia interaktif pada pembelajaran Matematika, yaitu untuk (1) mengetahui penggunaan multimedia interaktif dengan Adobe Flash Palyer CC pada pembelajaran Matematika, (2) mengetahui layak dan tidaknya multimedia interaktif dengan Adobe Flash Palyer CC sebagai alat peraga yang baru, sebagai perbaikan atau pengganti media dan alat peraga yang terdahulu, (3) serta melihat efektifitasnya yang ditujukan pada keterampilan hipotesis siswa dan hasil belajar dengan menggunakan multimedia interaktif dengan Adobe Flash Palyer CC.

\section{METODE PENELITIAN}

Prosedur penelitian yang digunakan merupakan penelitan pengembangan yang dikembangkan oleh Thiagarajan, dengan tapap penelitian 4D yang telah dikembangkan bersama dan Semmel (Trianto, 2010:189) dengan tahapan model 4D adalah sebagai berikut :

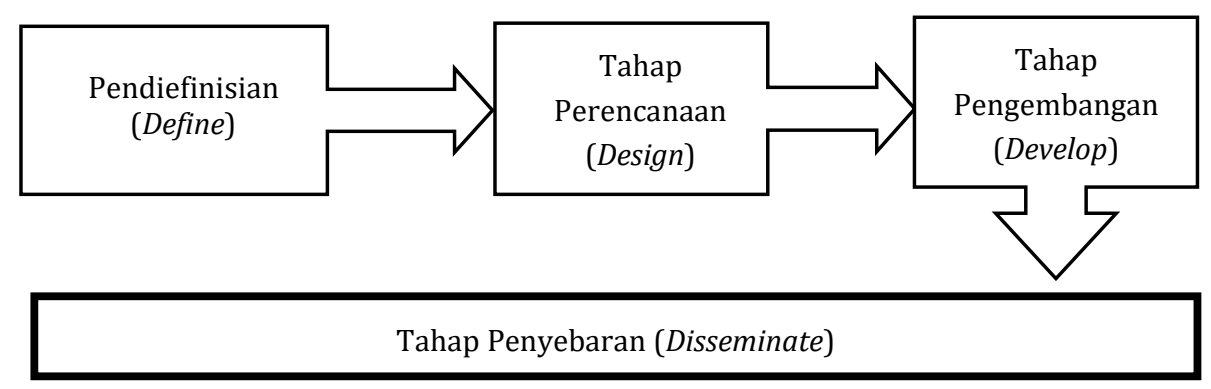

Gambar 1, Tahap Pengembangan 4D

Tahap Pendefinisian (define) dalam tahap ini diawali dengan melakukan observasi kedalam kelas pembelajaran yang bertempat di SD Negeri Sampetan pada pembelajaran matematika untuk mencari masalah yang terjadi saat pembelajaran biasa berlangsung. Serta melakukan wawancara terhadap Siswa, Guru, dan Kepala Sekolah mengenai permasalah yang sering muncul dalam pembelajaran Matematika terkait penggunaan media pembelajaran, setelah melakukan observasi dan wawancara didapatkan beberapa masalah terkait penggunaan media yang terdapat di Sekolah diantaranya belum efektifnya penggunaan media terhadap pembelajaran Matematika, kurangnya inovasi dalam penggunaan media, serta menurunya minat siswa belajar matematika menggunakan media yang terbatas. Dari beberapa permasalahan tersebut pengembangan dilanjutkan dengan analisis kebutuhan aplikasi dengan tujuan dapat menyelesaikan malasah yang ada serta dapat menjadi pembaruan media dalam pembelajaran matematika yang lebih efektif, komunikatif, dan efisien dalam pembelajaran Matematika terkait materi Bangun Datar.

Tahap Perencanaan (design) dalam tahap ini penelitian dilakukan dengan membuat desain use case dengan tujuan untuk merencanakan penggunaan media dalam pembelajaran dan penelitian memilih metode user use case dimana dalam realisasi penggunaan media siswalah yang menggunakan media dan 
dibimbing oleh guru, sehingga kapasitas guru dalam penyampaian materi pembelajaran hanya $20 \%$. dilanjutkan dengan perencanaan tes acuan patokan merupakan langkah yang menghubungkan pendefinisian dengan tahap perencanaan. Dengan membuat kisi-kisi tes sebagai patokan spesifikasi tujuan pembelajaran dan analisis siswa, dilanjutkan dengan pemilihan media untuk mengidentifikasi media yang relefan dengan karakteristik materi media dipilih untuk menyesuiakn dengan analisis konsep dan analisis tugas dengan atribut yang berfariasi dari media yang berbeda. Setelah media didapatkan maka penelitian dapat dilanjutkan dengan memilih format media, pemilihan format dimaksudkan untuk mendesain atau merancang isi pembelajaran, pemilihan strategi, pendekatan, metode pembelajaran dan sumber belajar.

Tahap Pengembagan (develop) yang digunakan untuk menghasilkan produk pengembangan yang baik melalui dua langkah, yakni (1) penilaian ahli yang diikuti dengan revisi, dalam penilaian ahli terdapat beberapa pakar ahli yang diikutsertakan dalam penilaian. Ahli materi untuk megetahui format isi, bahasa dan materi yang terdapat dalam media, ahli media untuk mengetahui format bahasa, tampilan, isi, kemudahan penggunaan, dan keterbaruan media, serta ahli pembelajaran untuk menilai penggunaan media dalam pembelajaran secara langsung dengan harapan media dapat memenuhi tujuan pembelajaran. (2) uji coba pengembangan dilakukan untuk memperoleh masukan langsung berupa respon, reaksi, komentar siswa, dan para pengamat terhadap media yang telah disusun.

Tahap Penyebaran (Disseminate) merupakan suatu tahap akhir pengembangan yang dilakukan untuk mempromosikan produk penggunaan agar bisa diterima pengguna, baik individu, suatu kelompok atau sistem. Dalam penelitian ini penyebaran dilakukan terhadap suatu kelas di SD Negeri sampetan. Penyebaran dalam penelitian ini dibagi menjadi 2, (1) penyebaran dilakukan di kelas IV yang digunakan untuk mengetahui peningkatan hasil belajar siswa, respon siswa terhadap media dan pengeruh media terhadap pembelajaran, (2) penyebaran dilakukan terhadap 10 siswa dari kelas V SD Negeri Sampetan yang dilakukan untuk mengetahui efektifitas penggunaan perangkat dalam pembelajaran. Sedangkan hasil akhir dari penelitian ini adalah CD multimedia interaktif serta video interaktif yang diharapkan dapat menjadi media baru untuk pembelajaran Matematika.

Hipotesis penelitian pengembangan ini antara lain, (1) multimedia interaktif dengan Adobe Flash Palyer CC yang dikembangkan layak digunakan dalam pembelajaran Matematika (2) multimedia interaktif dengan Adobe Flash Palyer CC yang dikembangkan efektif dalam mencapai tujuan pembelajaran, (2) multimedia interaktif dengan Adobe Flash Palyer CC yang dikembangkan efisien dalam mencapai tujuan pembelajaran, dan (3) multimedia interaktif dengan Adobe Flash Palyer CC yang dikembangkan memiliki daya tarik bagi siswa.

\section{ANALISIS DAN PEMBAHASAN}

Hasil penelitan pengembangan menujukan hasil uji coba media interaktif dengan Adobe Flash Player CC pada mata pelajaran Matematika kompetensi dasar Memahami sifat-sifat Bangun Datar, hubungan antar Bangun Datar, dan rumus Bangun Datar. Yang dilakukan terhadap siswa kelas IV SD Negeri sampetan yang digunakan untuk mengetahui peningkatan hasil belajar siswa dalam mempelajari dan mengembangkah proses belajar memahami konsep dan meningkatkan proses berfikir kritis siswa. Sebelum dilakukan uji coba penggunaan media secara luas, media diuji oleh beberapa ahli yang telah dipilih untuk mengetahui kelayakan media serta merevisi media sehingga media dapat dikatakan layak untuk digunakan, dilajutkan dengan uji terbatas yang digunakan untuk mengetahui pengaruh media sebelum dipakai dalam suatu kelas.

Berdasarkan hasil validasi dari beberapa ahli menyatakan bahwa multimedia interaktif yang dikembangkan untuk mata pembelajaran Matematika kompetensi dasar Memahami sifat-sifat Bangun Datar, hubungan antar Bangun Datar, dan rumus Bangun Datar layak digunakan dan dikembangkan. Dengan demikian media dapat diujicobakan kepada siswa pada kelompok terbatas serta kelompok luas untuk mengetahui peningkatan hasil belajar siswa serta mengetahui efektifitas, efisiensi dan daya tarik media terhadap pembelajaran

Multimedia interaktif Adobe Flash Player CC pada penggunaanya terhadap kelompok terbatas mendapatkan hasil yang cukup signifikan yang dapat dilihat dari hasil pre-test dan pos-test dengan peningkatan rata-rata tes $60 \%$ menjadi $79 \%$ siswa yang lulus tes dengan setandar nilai ketuntasan minimum belajar 78. Dari 49 komponen pembelajaran dalam media, 30 komponen terlaksana dengan baik, 10 komponen terlaksana tetapi belum optimal, dan 9 komponen belum terlaksana dikarenakan keterbatasan waktu pelaksanaan. Sedangkan dalam uji coba lebih luas didapatkan hasil rata-rata siswa yang lulus dalam pembelajaran $70 \%$ menjadi $90 \%$ lulus dengan standar nilai ketuntasan minimum 7,8 dan peningkatan rata-rata nilai kelas yang meningkat dari 60 menjadi 85, dengan proses kegiatan belajar mengajar yang optimal sesuai dengan prosedur serta ketercapaian semua komponen dalam media. 


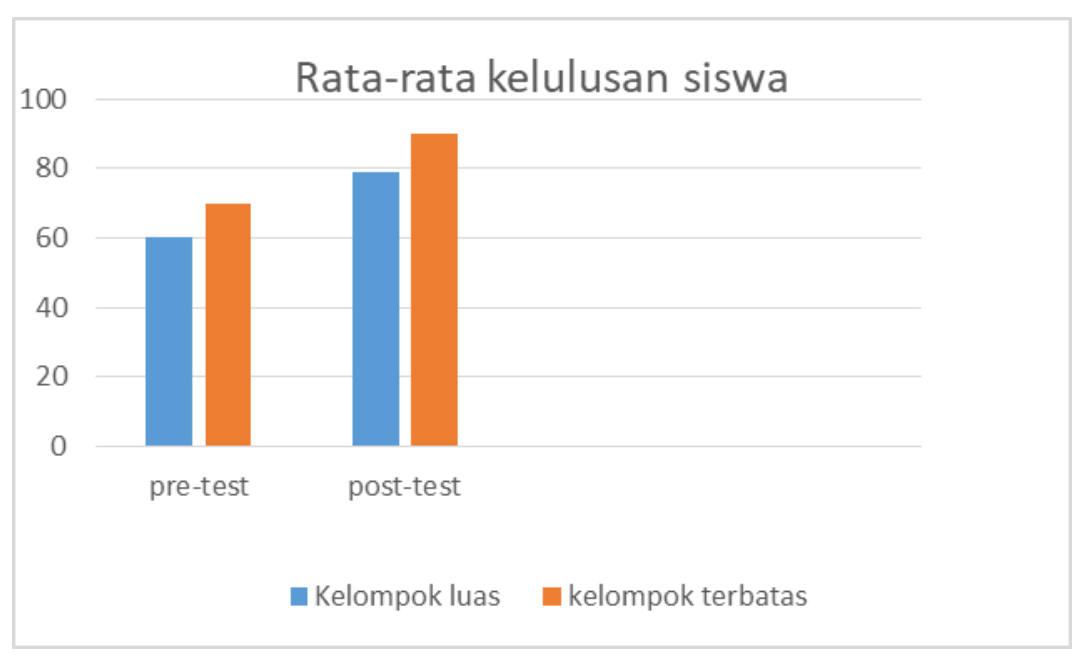

Gambar 2. hasil test kelompok siswa

Efektifitas multimedia interaktif menggunakan Adobe Flash Player CC dibuktikan pada hasil observasi aktifitas siswa pada uji coba terbatas dan lebih luas. Berdasarkan observasi dari uji coba terbatas sikap siswa yang dinilai seperti perhatian, respon, penghargaan, dan antusia siswa terhadap multimedia interaktif Matematika kompetensi dasar Memahami sifat-sifat Bangun Datar, hubungan antar Bangun Datar, dan rumus Bangun Datar cukup baik namun masih dikatakan kurang optimal dengan persentasi rata-rata nilai mencapai $78 \%$. sedangkan dalam observasi pada uji coba yang lebih luas sikap siswa dan hasil belajar siswa menunjukan peningkatan yang sangat baik mencapai $90 \%$.

Efisiensi multimedia interaktif menggunakan Adobe Flash Player CC Matematika kompetensi dasar Memahami sifat-sifat Bangun Datar, hubungan antar Bangun Datar, dan rumus Bangun Datar dapat diukur dari penggunaan waktu yang dibutuhkan guru untuk melakukan pembelajaran serta penggunaan media yang dilakukan oleh siswa untuk memahami materi. Hal ini dibuktikan dari wawancara terhadap guru mengenai penggunaan multimedia dalam pembelajaran yang dilakukan, guru mengangap bahwa kegiatan belajar mengajar lebih praktis, mudah dipahami, memiliki banyak sub materi yang sangat membantu dalam pembelajaran serta membuat siswa lebih tertarik untuk belajar dengan media yang baru.

Berdasarkan hasil ujicoba terbatas yang hanya membutuhkan waktu 1 kali pertemuan dengan jangka waktu 4 x 35 menit, serta ujicoba yang lebih luas dengan rentan waktu yang sama untuk menyampaikan materi sifat-sifat Bangun Datar, hubungan antar Bangun Datar, dan rumus Bangun. Keseluruhan waktu yang digunakan untuk menyampaikan materi sebanyak 2 kali pertemuan lebih singkat dibanding dengan tidak menggunakan multimedia interaktif sehingga pembelajaran lebih efisien dibandingkan dengan tidak menggunakan media.

Daya tarik pada penggunaan media yang dilakukan pada ujicoba terbatas dengan melakukan observasi pada siswa diperoleh rata-tara kemenarikan yang didapat $70 \%$ sehingga media tersebut masih membutuhkan perbaikan dikarenakan termasuk pada tingkatan cukup. Sedangkan pada ujicoba yang lebih luas didapat hasil rata-rata kemenarikan penggunaan media setelah direvisi mendapatkan hasil $85,7 \%$ artinya berada pada tingkat kemenarikan baik, sehingga dapat disimpulakn bahwa penggunaan multimedia pada pembelajaran Matematika yang dilakukan memiliki daya tarik pada siswa.

Proses berfikir kritis serta pemecahan masalah pada penggunaan media yang dilakukan pada uji coba terbatas dan uji coba lebih luas dilihat dari hasil pre test dan pos test yang dilakukan menujukan hasil yang signifikan. Dari pengamatan rata-rata nilai yang meningkat serta kesalahan pengerjaan pada beberapa soal dapat diartikan siswa mampu memecahkan masalah dengan lebih mudah setelah penggunaan media pada pembelajaran Matematika. Sehingga dapat disimpulkan penggunaan media interaktif dapat meningkatkan proses berfikir kritis serta pemahaman konsep yang lebih baik dibanding kanpenggunaan media sebelumnya.

Tujuan penelitian ini adalah untuk mengetahui peningkatan hasil belajar siswa dalam pembelajaran Matematika serta bagaimana pengaruh peningkatan proses berfikir kritis dan pemahaman konsep siswa di SD Negeri Sampetan. Penggunaan multimedia interaktif dalam pembelajaran di sekolah merupakan salah satu kegiatan yang dapat meningkatkan motivasi belajar peserta didik. Hal tersebut karena penggunaan media khususnya multimedia interaktif merupakan suatu cara yang dilakukan agar pembelajaran terasa menyenangkan, tidak membuat peserta didik merasa bosan, mengantuk dan lebih membuat peserta didik memahami materi yang diberikan oleh guru. Namun tidak semua pembelajaran 
dilakukan dengan menggunakan multimedia interaktif. Multimedia interaktif ini digunakan untuk memperoleh suatu pembelajaran yang tidak monoton, dan membantu peserta didik untuk mendapatkan pembelajaran yang menyenangkan.

Tujuan dari penggunaan multimedia interaktif bukan hanya memperoleh pembelajaran yang menyenangkan tetapi juga dapat meningkatkan keinginan peserta didik untuk lebih semangat dalam mempelajari suatu materi khususnya materi Pendidikan Matematika di sekolah, di rumah, dan mendapatkan hasil yang maksimal dan membanggakan. Penggunaan multimedia interaktif ini menunjukkan bahwa ada pengaruh yang cukup baik terhadap motivasi siswa dalam mengikuti proses pembelajaran. Motivasi merupakan satu faktor utama yang harus diperhatikan agar tujuan pembelajaran dapat tercapai dengan maksimal dan dapat menumbuhkan interaktsi yang positif dalam proses pembelajaran.

Pemilihan metode pembelajaran juga berpengaruh terhadap proses berfikir kritis siswa. Guru harus mampu menggunakan metode dengan baik agar siswa tertarik dengan materi yang sedang dipelajari, seperti halnya dapat menggunakan media pembelajaran. Penggunaan multimedia interaktif dapat menumbuhkan berfikir kritis dalam proses pembelajaran, karena didalam multimedia tersebut terdapat perpaduan dari berbagai komponen yaitu: teks, audio, video, games dan juga evaluasi yang dikemas menjadi satu komponen untuk memudahkan siswa dalam belajar dan dirancang agar siswa juga dapat dengan mudah mengoperasikannya sehingga siswa ikut berperan dan terlibat langsung dalam proses pembelajaran agar siswa lebih mengerti setiap materi yang dipelajari. Multimedia ini cukup membuat siswa tertarik dan tidak merasa jenuh ataupun bosan pada saat proses pembelajaran berlangsung dibandingkan siswa hanya belajar melalui buku teks. Melalui multimedia interaktif itulah proses pembelajaran terlihat lebih aktif, sehingga terbangun suasana yang menyenangkan dan interaksi yang baik didalamnya.

Dapat memecahkan masalah melalui pemahaman yang lebih luas adalah tujuan yang diharapkan dari belajar Matematika pembelajaran menggunakan media yang baik akan menumbuhkan sikap baru yang membuat siswa lebih mudah dalam memecahkan suatu persoalan yang ia hadapi. Penggunaan multimedia intreaktif yang baik akan membuat proses belajar memecahkan masalah dan memahami konsep baru akan lebih mudah dilakukan, karena didalam media terdapat berbagai persoalan yang harus bisa diselesaikan oleh siswa melalui soal latihan yang terdapat dalam setiap materi serta kejelasan materi yang disampaikan menggunakana animasi. Dewi (2011) dalam skripsinya yang berjudul "Pengembangan Multimedia Pembelajaran Matematika "Math-Tainment" Materi Pokok Garis dan Sudut untuk SMP Kelas VII". Hasil penelitian pengembangan media pembelajaran dinyatakan efektif dilihat dari ketuntasan belajar siswa yang mencapai $68,75 \%$, respon positif siswa mencapai $78,18 \%$, dan respon positif guru mencapai $83,84 \%$. Malalui multimedia interaktif itulah pembelajaran yang menumbuhkan proses pemahaman konsep baru serta pemecahan masalah dapat dilakukan, sehingga terbangun suasana belajar baru yang lebih menyenangkan.

\section{KESIMPULAN}

Berdasarkan hasil penelitian pengembangan yang telah dilakukan, maka peneliti dapat menyimpulkan bahwa penggunaan multimedia interaktif pada pembelajaran Matematika kompetensi dasar Memahami sifat-sifat Bangun Datar, hubungan antar Bangun Datar, dan rumus Bangun Datar yang dikembangkan layak untuk digunakan efisien, efektif dalam pembelajaran. Serta dapat menumbuhkan proses berfikir kritis, meningkatkan pemahaman konsep, dan proses pemecahan masalah yang lebih mudah dipahami dalam belajar Matematika bagi siswa kelas IV SD Negeri Sampetan, alokasi waktu yang singkat serta kemudahan penggunaan adalah tujuan dari pembuatan multimedia interaktif yang diharapkan.

\section{DAFTAR PUSTAKA}

Asmara, Anjar Purba. 2015. Pengembangan Media Pembelajaran Berbasis Audio Visual tentang Pembuatan Koloid. Jurnal Ilmiah Didaktika Vol. 15 No. 2 Hal. 156-178. Tersedia Pada: https://jurnal.ar-raniry.ac.id/index.php/didaktika/article/view/578/481.

Agustien, Relis, Nurul Umamah, Sumarno. 2018. Pengembangan Media Pembelajaran Video Animasi Dua Dimensi Situs Pekauman di Bondowoso Dengan Model Addie Mata Pelajaran Sejarah Kelas X IPS. 
Jurnal Edukasi 2018, Vol. V No. 1 Hal. 19-23. Tersedia Pada: https://jurnal.unej.ac.id/index.php/JEUJ/article/view/8010.

Arsyad, A. 2007. Media Pembelajaran. Jakarta: PT RajaGrafindo Persada.

Hamdani. (2010), Strategi Belajar Mengajar, Bandung: Pustaka Setia.

Johari, Andriana Syamsuri Hasan, Maman Rakhman. 2014. Penerapan Media Video dan Animasi Pada Materi Memvakum dan Mengisi Refrigeran terhadap Hasil Belajar Siswa. Journal of Mechanical Engineering Education, Vol.1, No.1, Hal. 8-15. Tersedia Pada: http://ejournal.upi.edu/index.php/jmee/article/view/3731.

Musfiqon. (2012), Pengembangan Media dan Sumber Pembelajaran, Jakarta. PT. Prestasi Pustakarya.

Rani Kristina Dewi (2011)."Pengembangan Multimedia Pembelajaran Matematika "Math-Tainment" Materi Pokok Garis dan Sudut untuk SMP Kelas VII”, Lambung Pustaka Universitas Negeri Yogyakarta.

Sanjaya, Rangga. (2016), Multimedia Interaktif Pelatihan Service Excellent Menggunakan Pendekatan Story Based Learning, Jurnal Informatika, Volume III No.1, April 2016: 101-102).

Sukiyasa, Kadek, Sukoco. 2013. Pengaruh Media Animasi terhadap Hasil Belajar dan Motivasi Belajar Siswa Materi Sistem Kelistrikan Otomotif. Jurnal Pendidikan Vokasi, Vol 3, Nomor 1, Hal. 126-137. Tersedia Pada: https://journal.uny.ac.id/index.php/jpv/article/view/1588.

Trianto. (2010). mendesain pembelajaran innovatif-progresif, American Juornal of Education Reserch, vol 3 no.10, 1298-1312. 